D. Matushkin, graduate student ORCID 0000-0003-4431-7862

A. Bosak, Cand. Sc. (Eng.), Assoc. Prof., ORCID 0000-0003-0545-9980

L. Kulakovskyi, Cand. Sc. (Eng.), Senior Lecturer ORCID 0000-0003-1273-6894

National Technical University of Ukraine

"Kyiv Polytechnic Institute named after Igor Sikorsky"

\title{
ANALYSIS OF FACTORS FOR FORECASTING ELECTRIC POWER GENERATION BY SOLAR POWER PLANTS
}

The new model of the wholesale electricity market in Ukraine causes appearance the market for the day ahead. In this market, the generating company undertakes to supply a certain amount of electricity. So, it is necessary to carry on the most accurate forecast of possible electricity generation by solar power plant (SPP). Generation value depends on certain factors. A brief summary of different influence of parameters on the PV cell performance has been provided. The article analyzes and identifies the factors that should be included in the forecast mathematical model of electricity generation by a solar power plant for a certain short-term period. According to analyzed data from SPP located in the Kyiv region, such parameters are the intensity of solar radiation, temperature and humidity, wind speed, and atmospheric pressure. The degree of influence of these factors on the initial function of electric energy generation were estimated by analyzing the scatter plot diagrams of relationship between parameters and correlation coefficients. Thus, the analysis of the influence of factors on the magnitude of electricity generation allowed to determine the priority of including each of the parameters in the mathematical model of the SPP power forecast. It was established that the influence of certain climate parameters for target function is different in each season. Therefore, in the mathematical model for forecasting electric power generation, it is necessary to take into account seasonality. In addition, the dynamic value change of factors also affects the current magnitude of electricity generation. Moreover, at different times of the year and with different combination of the corresponding values of climatic parameters, this effect may have different magnitudes. Therefore, the data obtained from the last periods before the forecasting should have a greater impact on obtaining the predicted value than the data from previous periods.

Keywords: forecasting, electricity generation, solar power plant, correlation matrix, intensity of solar radiation.

Introduction. The wholesale electricity market (WEM) must move to a new operational model according to the regulation's rules adopted by now in Ukraine. This market has been implemented in many foreign countries and is called the model of bilateral agreements and balancing market [1]. One of its distinctive features is organization the general structure of the WEM market for the day ahead with the balancing part. This market allows supplier to purchase additional amount of electricity or sale excessively ordered amount at auction. It causes the appearance of new organizational management issues. Resolving of these tasks requires the development of fundamentally new means of automation the management processes and mathematical modeling that should base on modern mathematical methods. One of such tasks is operational daily planning of electricity supplies inside of the wholesale market. It is impossible without accuracy forecast of generated electricity. The generation of electricity by a solar power plant (SPP) depends on climatic conditions that change over time. To overcome this issue, it is important to use new intelligent methods that take into account value of all parameters which affect the accuracy of the forecast [2].

Purpose and objectives. The aim of the work is to determine the patterns for forecasting the amount of electricity generated by solar power plants on the short-term period depending on climatic parameters. These patterns will allow to build forecasting mathematical models. Determination the list of climatic factors, the degree and nature of their impact on the output capacity of the SPP is needed to build dependencies and farther conclusions.

Material and research results. One of the most important factors determining the change of the amount of electricity generation in the short term is climate change. The main such climate factor is the intensity of solar radiation, $\mathrm{W} / \mathrm{m}^{2}$. The voltage produced by the solar cell depends on the incident light flux, namely: the voltage increases with increasing illumination to a certain scale. The next factor that should be highlighted is the ambient temperature. It directly affects heating of the panels. Most panels are designed to operate in temperature mode from $-40{ }^{\circ} \mathrm{C}$ to $+80{ }^{\circ} \mathrm{C}$. More lower ambient temperature indicates a more higher level of conversion [3]. For example, a 270 -watt panel in hot summer with $+35^{\circ} \mathrm{C}$ temperature generate $257 \mathrm{~W}$ of electricity, and in winter at $-20^{\circ} \mathrm{C}-298 \mathrm{~W}$ [4]. This is due to the fact that with increasing temperature, the flow of electrons inside the element increases. Process of increasing electrons' flow causes an increase current and decrease voltage. The

(C) Д.С. Матушкін, А.В. Босак, Л.Я. Кулаковський, 2020 
voltage decreases faster than the current increases. Therefore, the total power $(P=U I)$ decreases and the efficiency of the panel is reducing. Manufacturers indicate the value of the temperature coefficient of the panel for the numerical characteristic of the decreasing the electrical energy generation caused by increasing temperature of the solar panel. The temperature coefficient is a parameter that indicates how much the efficiency of the solar panel decreases with increasing air temperature by each degree. The value of this factor is obtained experimentally by the manufacturer and indicated in the specifications. In summer the temperature of panel can rise to $60-70{ }^{\circ} \mathrm{C}$. On average, rising temperature by $20^{\circ} \mathrm{C}$ cause the loss of power generation to about $10 \%[5]$.

The influence of air humidity on the efficiency of solar panels was studied in [6-8]. Experiments conducted in $[8$ showed that humidity significantly affects the performance of the solar panel. The generation of electricity from solar panels can be reduced to $15-30 \%$ depending on the humidity level, as high humidity can form a layer of water on their surface. In this case, the probability for appearing clouds, fogs and scattering radiation also increases. In [6] it was shown that an increase in humidity by $5 \%$ causes a decrease in efficiency by $7.5 \%$, by $10 \%$ $-15.8 \%$, and by $25 \%-30 \%$.

The next parameter that affects the amount of electricity generation is the wind speed. By increasing the wind speed, more heat can be removed from the surface of the photocells. Also, higher air velocity reduces the relative humidity of the atmosphere. It leads to improved efficiency. Conversely, the wind raises dust and disperses it in the environment, which can lead to shading and poor performance of photovoltaic cells [9].

The summary of the results is shown in Table 1.

Table 1 - A brief summary of different influential parameters on the PV cell performance

\begin{tabular}{|l|l|l|l|l|}
\hline & Dust & Humidity & Air Velocity & Efficiency \\
\hline Dust & More dust settlement & Insignificant effect & Insignificant effect & Drops \\
\hline Humidity & $\begin{array}{l}\text { Causes more dust } \\
\text { coagulation }\end{array}$ & - & Insignificant effect & Mostly drops \\
\hline $\begin{array}{l}\text { Air } \\
\text { Velocity }\end{array}$ & $\begin{array}{l}\text { More dust deposition } \\
\text { Less dust deposition }\end{array}$ & Decreases & - & $\begin{array}{l}\text { Surges occasionally } \\
\text { Improves }\end{array}$ \\
\hline
\end{tabular}

It is also worth noting the possibility of influencing the wind direction. Depending on the angle at which the wind blows to the panels, the effect of wind speed on the efficiency of the panels may increase or decrease. The direction of the wind can also affect the shading of the panels by the deposition of dust or snow. The snow will settle better on the surface if the wind blows directly on the panel. The influence of wind direction on the placement of modules needs to be further investigated.

It is a known that before bad weather (precipitation) the atmospheric pressure drops, and before clear (dry) weather - the pressure increases [10]. Short-term precipitation has small effect on efficiency. However, significant rainfall is usually character in cloudy weather. Radiation and, accordingly, generation in this situation are reduced. Atmospheric pressure by itself is not a factor that directly affects the level of electricity generation. But it has an indirect effect on the main factors. In general, depending on the increase or decrease of atmospheric pressure, the influence of temperature, wind and humidity on energy production can increase or decrease.

Consider the degree of influence of factors on the value of electricity generation on the example of SPP in the village Dymerka, Kyiv region. The data consist of more than 26 thousand samples collected from July 1, 2020 to December 31, 2020. They are characterizing the operating conditions of solar panels (9 MW).

The data set consists of two types of data:

1) Weather data. The first part of the data consists of measured weather parameters such as temperature, solar radiation, humidity, atmospheric pressure, wind direction and speed.

2) Data from electricity counter. The second part - accounting of the amount of electricity sold to the external general network, including PV power, which is forecasting.

The data set consists of the actual value of electricity generation for 10-minute intervals (the electricity counter transmits the generation value to the monitoring point with a discreteness of 10 minutes) and the measured climatic parameters for this period.

We used a correlation matrix to estimate the actual value of the influence of each parameter on the objective function and separately on each of the input factors of the model. It is a structured approach for ranking the importance of predictors or input variables (input variables that have the greatest impact) on output function. The correlation coefficient for the sample is determined from the expression [11]:

$$
r_{x y}=\frac{\sum_{i=1}^{n}\left(x_{i}-\bar{x}\right)\left(y_{i}-\bar{y}\right)}{(n-l) s_{x} s_{y}}=\frac{\sum_{i=1}^{n}\left(x_{i}-\bar{x}\right)\left(y_{i}-\bar{y}\right)}{\sqrt{\sum_{i=1}^{n}\left(x_{i}-\bar{x}\right)^{2} \sum_{i=1}^{n}\left(y_{i}-\bar{y}\right)^{2}}}
$$


where $\bar{x}, \bar{y}$ - the average values for the sample $x$ and $y, s_{x}$ and $s_{y}$ - unbiased (adjusted) estimate of the standard deviation for $x$ and $y$.

A positive value of the coefficient indicates direct influence of each factors. In case the value of a certain parameter increases, the value of the second placed at the intersection of the matrix also increases and vice versa. For this purpose, a thermal map of the correlation matrix (Fig. 1) was constructed. It basis on the data from the half-year operation of the solar panel with 10-minute discreteness.

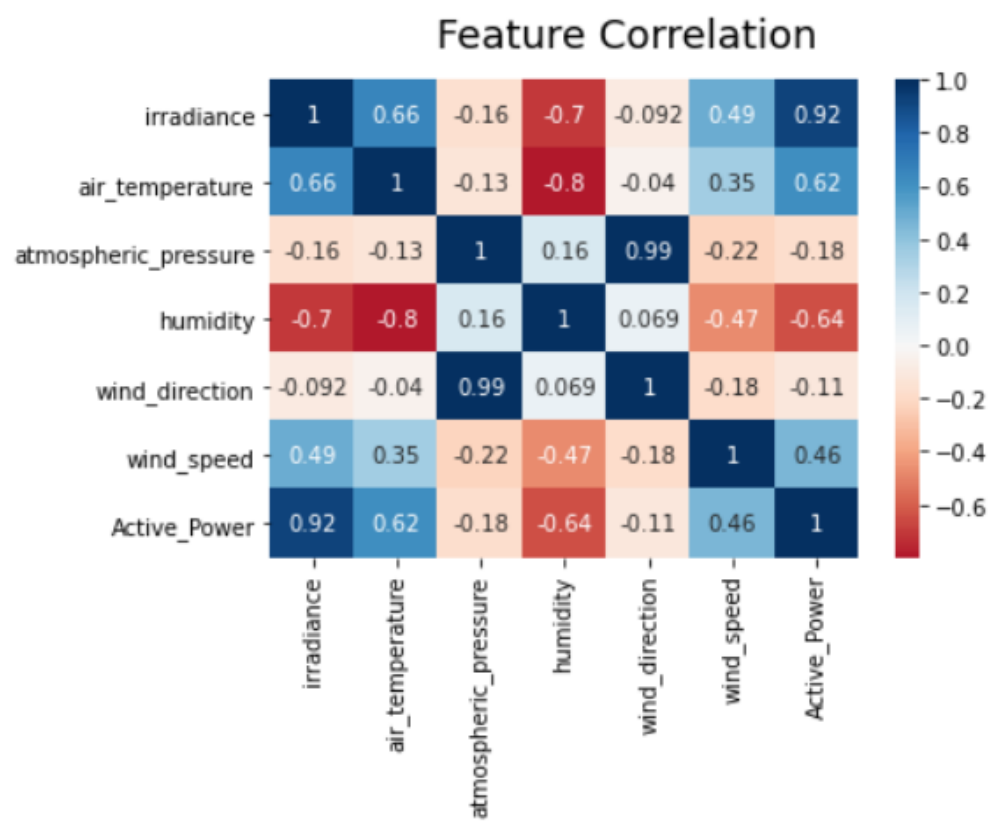

Figure 1 - Correlation matrix

Three parameters have positive correlations with the output - active power generation. Such parameters are solar radiation $(92 \%)$, air temperature $(62 \%)$ and wind speed $(46 \%)$. And relatively humidity has negative correlation. It should be noted that the wind direction is correlated with atmospheric pressure of $99 \%$. This means that the values change of one parameter almost completely depending on the value of another. In other words, these factors in the model will be duplicated. And this will increase the complexity of the model, may increase the error of the model and increase the possibility of retraining. Therefore, the "wind speed" parameter is excluded from the model.

A scatter plot diagram of electric power generation values with solar radiation parameters is shown on Fig. 2, with ambient temperature on Fig. 3, with wind speed on Fig. 4 for the studied period at 10-minute intervals.

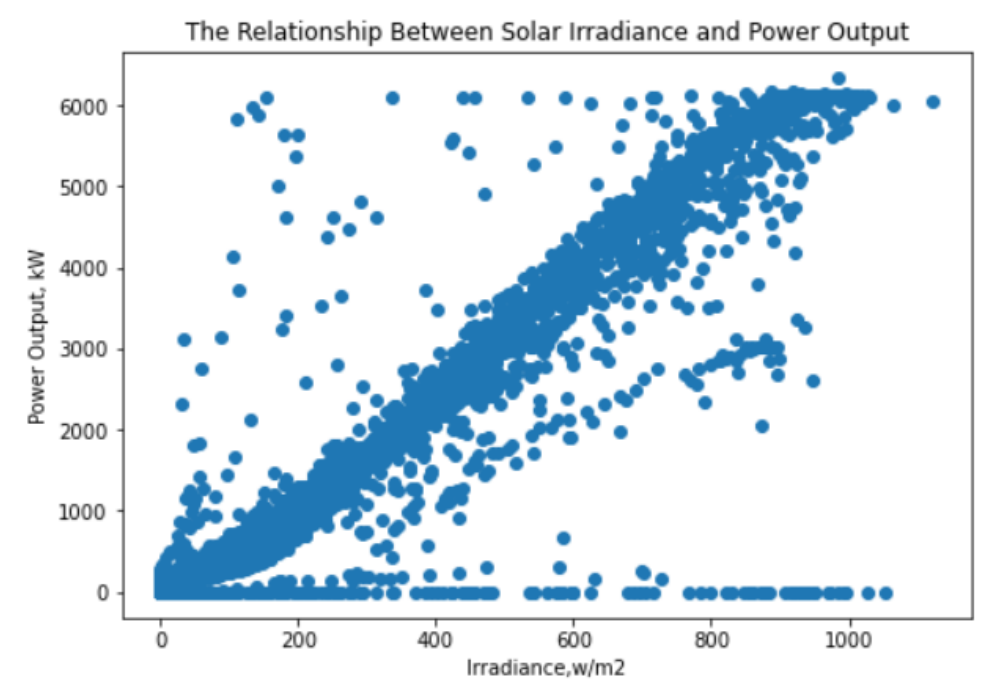

Figure 2 - Dependence of the output electric power generation of the SPP on solar radiation 


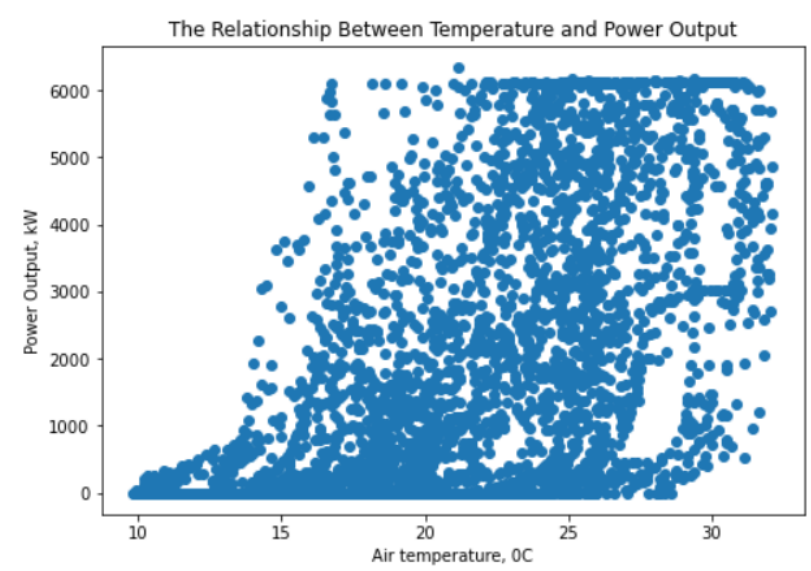

Figure 3 - Dependence of the output electric power generation of the SPP on the ambient temperature

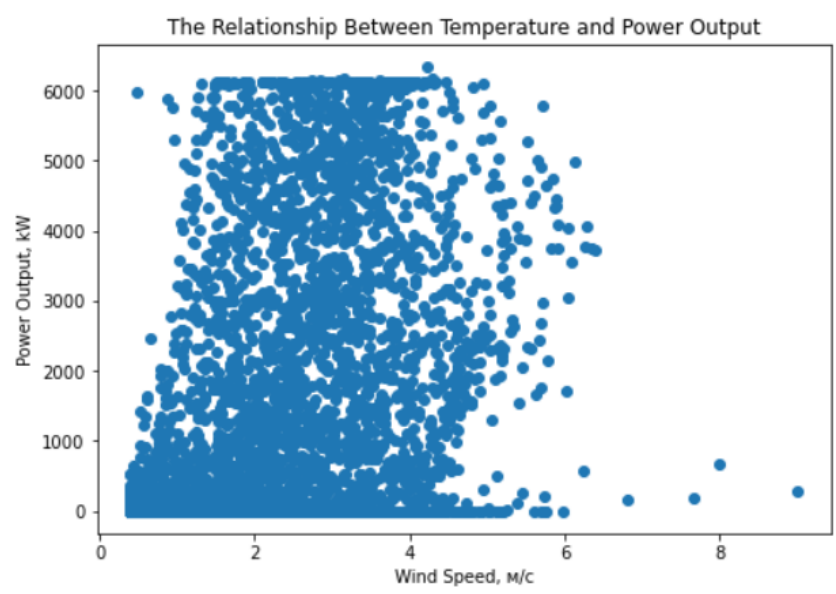

Figure 4 - Dependence of the output electric power generation of the SPP on wind speed

Figure 2 shows a linear relationship between the parameters of solar radiation and output power generation with a certain amount of data emissions. Instead, there is no clear dependence of electricity generation data with wind speed and ambient temperature. This once again indicates that the main parameter that affects the amount of electricity generation of SPP - is the intensity of solar radiation. To determine the influence of other factors, it is necessary to analyze the tendency of change electricity generation at the constant values of solar radiation. Also, it should be analyzing the physical meaning of correlations and determine the sequence of including parameters into the model.

To do this, take a fragment of the input data (Table 2) for the forecasting of energy generation at the same value of solar radiation in the investigative period.

Table 2 - Fragment of data on climatic parameters and the amount of generation active electricity by the same level of solar radiation

\begin{tabular}{|c|c|c|c|c|c|c|c|c|}
\hline $\begin{array}{c}\text { Timest } \\
\text { amp } \\
\text { (day) }\end{array}$ & $\begin{array}{c}\text { Timestamp } \\
\text { (hours and } \\
\text { minutes) }\end{array}$ & $\begin{array}{c}\text { Solar } \\
\text { radiation, } \\
\mathrm{W} / \mathrm{m}^{2}\end{array}$ & $\begin{array}{c}\text { Air } \\
\text { temperature, } \\
{ }^{0} \mathrm{C}\end{array}$ & $\begin{array}{c}\text { Atmospher } \\
\text { ic pressure, } \\
\text { mBar }\end{array}$ & $\begin{array}{c}\text { Humidi } \\
\text { ty, } \%\end{array}$ & $\begin{array}{c}\text { Wind } \\
\text { directio } \\
\mathrm{n},{ }^{\circ}\end{array}$ & $\begin{array}{c}\text { Wind } \\
\text { speed, } \\
\mathrm{m} / \mathrm{s}\end{array}$ & $\begin{array}{c}\text { Active } \\
\text { Power, } \\
\mathrm{kW}\end{array}$ \\
\hline 02.07 & $8: 10: 00$ & 440,6 & 24,4 & 499,85 & 64,4 & 66,5 & 2,0 & 3984,4 \\
\hline 20.07 & $8: 20: 00$ & 440,6 & 21,0 & 500,13 & 66,1 & 104,2 & 1,1 & 4262,7 \\
\hline 13.10 & $13: 30: 00$ & 440,6 & 18,5 & 501,62 & 74,4 & 311,5 & 4,8 & 7102,5 \\
\hline 18.10 & $13: 20: 00$ & 440,6 & 7,7 & 500,44 & 64,2 & 141,3 & 5,3 & 7490,4 \\
\hline
\end{tabular}

On the table 2 the biggest energy generation by the same solar radiation $\left(\mathrm{W} / \mathrm{m}^{2}\right)$ was in the autumn month. The air temperature in July $2^{\text {nd }}$ was higher than July $20^{\text {th }}$ (above $25{ }^{\circ} \mathrm{C}$ ), and since it is a summer month, the surface temperature of the panel was higher. This reduces the generation of active power. However, the humidity 
on July $2^{\text {nd }}$ was higher and the wind speed was lower. According to the correlation analysis, these indicators should indicate that the generation of active power should be higher. Therefore, when the air temperature is more than $20^{\circ} \mathrm{C}$ with the same solar radiation. So, surface of panel is heated for more than $25^{\circ} \mathrm{C}$, the efficiency of the panels decreases. Other factors in this case have less influence on the amount of active power generation. Therefore, the air temperature, in addition to having the greatest direct relationship to solar radiation (in general, the amount of solar radiation is greater at higher air temperatures), has the biggest impact on the generation of active electricity at constant light level. And it is negative compare with positive correlation on the whole investigated period (fig. 1). According to table 1, in the autumn month the generation is almost on $30 \%$ higher. In this period air temperature is decrease and wind speed increase. It indicates the need to include in the model also the wind speed parameter. On October 18 , the electricity generation is bigger than on October $13^{\text {th }}$. In October, the air temperature had less effect than in summer on reducing the efficiency of the solar panel, and the wind speed was increased slightly. In this case, it is necessary to take into account the value of humidity that on October $13^{\text {th }}$ compared to October $18^{\text {th }}$ is $10 \%$ higher. Atmospheric pressure also increased. Therefore, at the last stage of the feature selection is necessary to include into the model the humidity parameters and then atmospheric pressure. And for the model of forecasting the intensity of solar radiation, it is necessary to take into account the change of climatic factors depending on the seasonality.

Discussion of results and conclusions:

It was established that the level intensity of solar radiation has the greatest influence on the generation of electric energy. Moreover, at different times of the year and in combination with the corresponding values of other climatic parameters, this effect may have different influence on output function. This indicates that to model for forecasting electricity generation in addition to the value of irradiance should include ambient temperature, wind speed, humidity, and in certain periods, atmospheric pressure. It was found that the value of electricity generation is based on the dynamics of data over time. That is why, high temperatures for several days (over $20^{\circ} \mathrm{C}$ ) cause the solar panels to heat up to high temperatures and, accordingly, reduce their efficiency. Therefore, in a ten-minute interval, the magnitude of lasing under such conditions will be lower than at short-term (several hours) the same temperature. Therefore, to build a mathematical model for the forecast of electricity generation for the day (hour) ahead, the degree of importance of the data taken immediately before the forecast will be higher than the data for previous periods. In addition, the forecast model should take into account the seasonality of the data, when changes in climatic parameters may affect the efficiency of solar panels in different ways.

Thus, the analysis of the influence of factors on the magnitude of electricity generation allowed to determine the priority of including each of the parameters in the mathematical model of SPP power forecast. In further research it is necessary to develop a model that separately calculated the generation forecasts for each period of the year and the dynamics of change of factors. Such a model can be built using a model of long-term short-term memory based on recurrent neural networks [12]. It can be used both for computer modeling of SPP operation and calculation of its technical and economic indicators, and for further analysis of SES operation as a part of combined energy systems with various energy sources, including RES.

\section{REFERENCES}

1. On the electricity market: Law of Ukraine № 2019-VIII of 13.04.2017 URL: http://zakon3.rada.gov.ua/laws/show/2019-19 (Accessed 21.07.2017). (Ukr)

2. Butenko V., Baidala V., Kozyrska T. Factors of solar electric power development in Ukraine. Investments: practice and experience. 2019. №17. Pp. 5-11. (Ukr)

3. Parsokhonov, Abdulkobi. Renewable Energy Source from Natural Thermal Expansion and Contraction of Matters. American Scientific Research Journal for Engineering, Technology, and Sciences (ASRJETS). 2016. Pp. 121-130.

4. Efficiency of solar panels URL: https://axiomplus.com.ua/news/effektivnost-solnechnyh-panelej/\#klimat. (Accessed 19.03.2021). (Rus)

5. Secrets of the best conditions for maximum efficiency of solar panels in systems under the "Green Tariff" URL: https://solarsystem.com.ua/zvit-pro-robotu-sonyachnyh-elektrostantsij-pid-zelenyj-taryf-za-traven-2018-roku (Accessed 19.03.2021). (Ukr)

6. Panjwani, Manoj Kumar, and G. Bukshsh Narejo. Effect of humidity on the efficiency of solar cell (photovoltaic). International Journal of Engineering Research and General Science. 2014. Vol 2.4. Pp. 499-503.

7. Park, N. C., W. W. Oh, and D. H. Kim. Effect of temperature and humidity on the degradation rate of multicrystalline silicon photovoltaic module. International Journal of Photoenergy. 2013. Vol. 2. Pp. 107-117.

8. Erdem, C. U. C. E., Pinar Mert CUCE, and B. A. L. İ. Tulin. Impact of humidity on current parame-ters of solar cells. Journal of Energy Systems. 2018. Vol. 2.3. Pp. 84-96.

9. Mekhilef, Saad, Rahman Saidur, and Masoud Kamalisarvestani. Effect of dust, humidity and air ve-locity on efficiency of photovoltaic cells. Renewable and sustainable energy reviews. 2012. Pp 2920-2925.

10. Singhania, Shalabh, et al. Temperature and seeding effects on the precipitation of scorodite from sulfate solutions under atmospheric-pressure conditions. Metallurgical and materials Transactions. 2005. Pp. 327-333.

11. Taylor, Richard. Interpretation of the correlation coefficient: a basic review. Journal of diagnos-tic medical sonography. 1990. Pp. 35-39. 
12. Pan, Cheng, et al. Very short-term solar generation forecasting based on LSTM with temporal attention mechanism. 2019 IEEE 5th International Conference on Computer and Communications (ICCC). IEEE, 2019.

УДК 621.316

Д.С. Матушкін, аспірант, ORCID 0000-0003-4431-7862

A.B. Босак, канд. техн. наук,доцент, ORCID 0000-0003-0545-9980

Л.Я. Кулаковський, канд. техн. наук, ст. викл., ORCID 0000-0003-1273-6894

Національний технічний університет України

«Київський політехнічний інститут імені Ігоря Сікорського»

\section{АНАЛІЗ ФАКТОРІВ ДЛЯ ПРОГНОЗУВАННЯ ГЕНЕРАЦЇ̈ ЕЛЕКТРИЧНОЇ ЕНЕРГІЇ СОНЯЧНИМИ ЕЛЕКТРОСТАНЦІЯМИ}

Нова модель оптового ринку електроенергї передбачає функиіонування ринку на добу вперед. На цьому ринку генеруюча компанія бере на себе зобов'язання по постачанню певної кількості електроенергї. Тому для сонячної електростанції (СЕС) необхідно здійснювати якомога точний прогноз можливого виробітку електроенергії, щзо залежить від певних факторів. В статті було проаналізовано та виділено фактори, що повинні бути включенні в прогнозну математичну модель визначення потужності сонячної електростаниії на певний короткостроковий період на основі даних СЕС розміщеної в Київській області., а саме інтенсивність освітлення, температура та вологість навколишнього середовища, швидкість вітру та атмосферний тиск. Здійснено аналіз ступеня впливу цих факторів на вихідну функцію генерації електричної енергї. Встановлено, щзо вплив певних кліматичних параметрів в залежності від пори року $\epsilon$ різним, а тому в математичній моделі прогнозу необхідно враховувати сезонність. Окрім иього, динаміка зміни значень факторів також впливає на поточну величину генерації електричної енергії. Тому дані отримані за останні періоди часу перед прогнозом повинні мати більший вплив на генерацію прогнозної величини аніж дані попередніх періодів.

Ключові слова:прогнозування, генерація електричної енергії, сонячна електростанція, коренляційна матриця, інтенсивність освітлення

\section{Список використаної літератури}

1. Про ринок електричної енергії: Закон України № 2019-VIII від 13.04.2017 p. URL: http://zakon3.rada.gov.ua/laws/show/2019-19 (дата звернення 21.07.2017).

2. Бутенко В. М., Байдала В. В., Козирська Т. О. Фактори розвитку сонячної електроенергетики в Україні. Інвестиії: практика та досвід. 2019. №17. С. 5-11.

3. Parsokhonov, Abdulkobi. Renewable Energy Source from Natural Thermal Expansion and Contrac-tion of Matters. American Scientific Research Journal for Engineering, Technology, and Sciences (ASRJETS). 2016. Pp. 121-130.

4. Эффективность солнечных панелей URL: https:/axiomplus.com.ua/news/effektivnost-solnechnyhpanelej/\#klimat. (дата звернення 19.03.2021).

5. Секрети найкращих умов максимальної віддачі сонячних батарей в системах під “Зелений тариф” URL: https://solarsystem.com.ua/zvit-pro-robotu-sonyachnyh-elektrostantsij-pid-zelenyj-taryf-za-traven-2018-roku (дата звернення 19.03.2021).

6. Panjwani, Manoj Kumar, and G. Bukshsh Narejo. Effect of humidity on the efficiency of solar cell (photovoltaic). International Journal of Engineering Research and General Science. 2014. Vol 2.4. Pp. 499-503.

7. Park, N. C., W. W. Oh, and D. H. Kim. Effect of temperature and humidity on the degradation rate of multicrystalline silicon photovoltaic module. International Journal of Photoenergy. 2013. Vol. 2. Pp. 107-117.

8. Erdem, C. U. C. E., Pinar Mert CUCE, and B. A. L. İ. Tulin. Impact of humidity on current parame-ters of solar cells. Journal of Energy Systems. 2018. Vol. 2.3. Pp. 84-96.

9. Mekhilef, Saad, Rahman Saidur, and Masoud Kamalisarvestani. Effect of dust, humidity and air ve-locity on efficiency of photovoltaic cells. Renewable and sustainable energy reviews. 2012. Pp 2920-2925.

10. Singhania, Shalabh, et al. Temperature and seeding effects on the precipitation of scorodite from sulfate solutions under atmospheric-pressure conditions. Metallurgical and materials Transactions. 2005. Pp. 327-333.

11. Taylor, Richard. Interpretation of the correlation coefficient: a basic review. Journal of diagnos-tic medical sonography. 1990. Pp. 35-39.

12. Pan, Cheng, et al. Very short-term solar generation forecasting based on LSTM with temporal attention mechanism. 2019 IEEE 5th International Conference on Computer and Communications (ICCC). IEEE, 2019. 